\title{
Flipped Learning in Engineering Modules Is More Than Watching Videos: The Development of Personal and Professional Skills
}

\author{
Fernando Suárez $^{1}\left(\mathbb{D}\right.$, Juan Carlos Mosquera Feijóo ${ }^{2}$ (D) , Isabel Chiyón ${ }^{3}$ and Marcos García Alberti $^{4, *(D)}$ \\ 1 Departamento de Ingeniería Mecánica y Minera, Universidad de Jaén, 23700 Linares, Spain; fsuarez@ujaen.es \\ 2 Departamento de Mecánica de Medios Continuos y Teoría de Estructuras, Universidad Politécnica de Madrid, \\ 28040 Madrid, Spain; juancarlos.mosquera@upm.es \\ 3 Departamento de Ingeniería Industrial y de Sistemas, Facultad de Ingeniería, Universidad de Piura, \\ Piura 20009, Peru; isabel.chiyon@udep.edu.pe \\ 4 Departamento de Ingeniería Civil Construcción, Universidad Politécnica de Madrid, 28040 Madrid, Spain \\ * Correspondence: marcos.garcia@upm.es
}

Citation: Suárez, F.; Mosquera Feijóo, J.C.; Chiyón, I.; Alberti, M.G. Flipped Learning in Engineering Modules Is More Than Watching Videos: The Development of Personal and Professional Skills. Sustainability 2021, 13, 12290 .

https://doi.org/10.3390/su1321 12290

Academic Editors: Marc Alier, María José Casañ and David

Fonseca Escudero

Received: 8 October 2021

Accepted: 3 November 2021

Published: 7 November 2021

Publisher's Note: MDPI stays neutral with regard to jurisdictional claims in published maps and institutional affiliations.

Copyright: (c) 2021 by the authors. Licensee MDPI, Basel, Switzerland. This article is an open access article distributed under the terms and conditions of the Creative Commons Attribution (CC BY) license (https:/ / creativecommons.org/licenses/by/ $4.0 /)$.

\begin{abstract}
The Accreditation Board for Engineering and Technology (ABET) has highlighted two key outcomes for students of all accredited engineering programs: the ability to communicate effectively with a range of audiences and the capacity to acquire and apply new knowledge as needed, using appropriate learning strategies. Likewise, in recent years, written exams, assignments, and oral presentations show transmission-skill deficiencies among engineering students. Flipped teaching serves to boost students to meet these outcomes and other competencies: comprehension reading, communication skills, character building, collaborative work, critical thinking, or creativity. So, flipped learning is more than watching videos. This research proposes two evidence-based transferable learning strategies built on a flipped-teaching model and was applied by the authors in engineering courses during the second year of the global pandemic caused by COVID-19: problembased learning and teamwork assignments. The study comprised two phases. First, a systematic review of reports, writings, and exams delivered by students. It included some video-watching analytics to detect misuse. In the second stage, the authors ascertained trends of these outcomes. Student perceptions and other achievement indicators illustrate the possibilities for encouraging learners to achieve transmission, communication, and literacy outcomes. Results indicate that these learner-centered approaches may help students learn better, comprehend, apply, and transmit knowledge. But they require an institutional commitment to implementing proactive instruction techniques that emphasize the importance of student communication skills.
\end{abstract}

Keywords: flipped learning; COVID-19; personal competencies; engineering outcomes; educational innovation; instructional materials; educational change; engineering education; meaningful learning

\section{Introduction}

The current ongoing digital transformation of universities is boosting a change in traditional academic life toward new approaches of educational and innovation settings [1-5]. Many universities are boosting vice-rectorates of strategy and digital transformation, which entails modernizing equipment, facilities, and digital media. Digital technology can leverage the learning experience in various aspects [6], thus becoming a key element in higher education [7], but must tackle three pending tasks: the digital divide, inclusion, and quality standards [8-11].

Current undergraduate Science, Technology, Engineering, and Mathematics (STEM) curricula focus on competencies and outcomes. These encompass knowledge, skills, and expected behaviors that students need to acquire as they progress throughout the syllabus, thus preparing them to enter professional practice [12-15]. Since 2000, the Accreditation Board for Engineering and Technology (ABET) has established outcomes-based criteria to 
characterize the skills, competencies, knowledge, and attitudes that engineering graduates should acquire [16,17]. More recently, ABET has highlighted two key outcomes, among seven, for students of all accredited engineering programs to foster improvement in the quality of education: the ability to communicate effectively with a range of audiences and the ability to acquire and apply new knowledge as needed, using appropriate learning strategies $[17,18]$. Flipped teaching can accomplish both targets, although it can also boost students to enhance other competencies: comprehension reading, applying acquired knowledge, improvement in written and verbal communication skills, character building, collaborative work, citizenship, critical thinking, and creativity, among others.

On the one hand, higher education agents have inherited the classical teacher-centered instruction model that requires covering all the material outlined in their syllabus. This model often hinders student engagement with the content during class. Current teaching trends shed light on the need to shift to the so-called "scientific teaching" $[19,20]$, plus a learner-centered approach that engages them, maintains rigor, builds on evidence, and considers their learning experiences, even stress [21-23]. Indeed, after the lockdown experience caused by the global pandemic, higher education is evolving to a safer, more flexible, and resilient learning environment [24]. Resilience implies the capacity to adapt to changing circumstances and can be achieved by implementing evidence-based teaching practices that encourage flexible approaches to learning, such as reducing cognitive load by amplifying core concepts and competencies, and redesigning assessment, among others [25].

On the other hand, university students carry digitally-based daily lives, so the higher education system definitely must harness the advantages of this ongoing digital transformation in the teaching-learning process. This digital-native student generation seems ready to learn differently than their predecessors [26-28]. However, the ways students use digital media in academic life and communicate with each other and with instructors often divert time to improve transmission and communication skills [5]. Hence, emphasizing communication instruction in technical modules helps students to transmit discipline-specific terms, facilitates learning transfer, and reveals that their profession values communicative skills [29]. If the online learning method and the digital resources presented by the teachers are attractive, both will encourage students to participate in active learning. In regards to evaluation, current pedagogical models and their implementation in ICT mediation tools-Learning Management Systems (LMS) and Classroom Response Systems (CRS), among others-usually build on quantitative and summative evaluation [30]. Nonetheless, evaluation must also be an opportunity to measure communication and transmission skills [31].

One of the clearest definitions of flipped learning was given by R. Talbert:

"Flipped Learning is a pedagogical approach in which first contact with new concepts moves from the group learning space to the individual learning space in the form of structured activity, and the resulting group space is transformed into a dynamic, interactive learning environment where the educator guides students as they apply concepts and engage creatively in the module matter... So the physical space for a flipped learning course has to enable active learning and allow for a variety of student choices in how they engage in this". [32]

Then, flipped learning is a methodology rather than a specific technique [33].

Flipped teaching has been sometimes assumed to consist of assigning videos of lectures for students to watch before class time. There is a massive practice to build flipped teaching on delivering instructional videos as the first stage, nevertheless, flipped learning is more than watching videos. Indeed, videos are not necessary to have a flipped learning environment. It aims to ensure that learners first encounter the new material autonomously, outside of class, and then work to shape up their understanding and build skills around the sought material in the class time. Hence, students develop the ability to grasp new material on their own and then do the more challenging work of integrating and 
developing its information in the classroom through the interplay with both classmates and the instructor $[33,34]$.

Thus, the flipped teaching model is suitable to accomplish the learner-centered experience as it can focus on a broader spectrum of competence achievements, including functional writing and transmission skills [35], and increase student active learning, social interaction [36], and performance [20,37]. The online-based flipped classroom learning method influences positively on learning outcomes [38,39]. Although the effectiveness of flipped teaching is widely accepted, some challenges of its application to higher education settings have also risen, such as the need for effective in-class learning designs and the necessity of helping students to learn across at-home and in-class contexts [40].

To accomplish the two aforementioned outcomes highlighted by ABET, engineering students must develop productive skills. However, instructors are seldom trained to teach and promote writing, as well as other communication skills. Instructors also need to acquire digital competencies, so experts in ICT can take full advantage of the potential that these technologies provide [41-44]. In this regard, one decade ago the American Association for the Advancement of Science (AAAS) undertook an extended process of dialog and reflection among all the stakeholders to seek excellence in the educational experience of undergraduates. Then, AAAS emphasized the importance of focusing on clear and aligned learning outcomes rather than on content coverage $[45,46]$, which results in improved student learning [39,47].

The written exams from recent years show an increasing lack of transmission and writing skills among undergraduate students, although such skills can be conveniently trained [29,48-50]. How to address such decay in communicative competence achievements and how to improve functional writing skills in technological engineering modules are increasingly a matter of concern. Otherwise, higher education stakeholders may be witnessing a lowering of the standards [51-53], sometimes accompanied by grade inflation. The latter has been foreseen since some decades ago [54-63] and is attributable to its positive effect on student evaluations of teaching [64-66], an increase in university competition [67], university policies [68,69], or to its connection with university rankings [70], among others.

The recent lockdown for the COVID-19 pandemic has significantly increased the number of videos and virtual classes, not always delivering improvements in the main skills sought. Online classes reduce social interaction, which has proved to be of special interest for the long-term learning issues since the first steps of student life [11,71].

This study proposes two evidence-based strategies based on the flipped teaching model that instructors can adopt to enhance engineering students' motivation toward acquiring transmission and communication skills: problem-based learning (PBL) and teamwork assignments. These learner-centered strategies can help students learn better and comprehend, apply, and transmit a module's core tenets to new situations [35,36,72].

This study belongs to a collaborative project carried out by professors of Universidad Politécnica de Madrid (UPM, Spain), Universidad de Jaén (UJA, Spain), and Universidad de Piura (UDEP, Perú). The methodology aims to help students improve their communication skills in engineering disciplines.

Section 2 describes a brief background on the two main topics analyzed in this study: some students' transversal competences and key aspects of online teaching. Section 3 briefly describes the main strategies followed in each module, which involve three universities, two from Spain and one from Peru. Then, Section 4 presents some findings in terms of how students perceive some strategies, the way they have used some materials, their engagement with the module, and their performance in written tests and exams. Section 5 discusses these results, and Section 6 contains the main conclusions. 


\section{Background}

\subsection{Some Required Transversal Competences in Engineering Instruction}

\section{- $\quad$ Reading comprehension}

Reading comprehension can be defined as the ability to understand a reading well and summarize it in detail $[73,74]$. It also means the skill of making meaning from whatever read text [75]. Reading comprehension is paramount in acquiring and applying new knowledge as needed, using appropriate learning strategies, in alignment with the mentioned ABET prescribed competence for engineers. Students are now digital natives, with very easy information access, derived by the use of the internet and smartphones, which makes it more difficult for them to reflect on a specific subject, since so much information is at their disposal through their own devices [76]. This sheds light on the need to complement watching videos with reading assignments, so that engineering students can achieve the diverse levels of knowledge and understanding in accordance with Bloom's taxonomy [73,77], i.e., to connect, generalize and related concepts, among others.

During the last few academic years, some reading difficulties have been observed that are clearly related to a lack of reading comprehension and the lessening of the amount of vocabulary that students are accustomed to use in receptive and productive language. As an example, in the module of Construction Management, students struggled to differentiate between a job site manager and a CEO of a company, showing a lack of overall culture that should have been learnt by reading the adequate books, newspapers, and journals. These physical supports may have changed to e-textbooks, mobile news, or online journals [78]. However, it seems that they have become more accustomed to WhatsApp, Twitter or LinkedIn formats, needing the minimum number of words and simplest possible manners to transmit a message. This means that long texts have disappeared from their daily tasks, thus reducing their vocabulary and their capacity to understand longer texts $[79,80]$.

- Writing skills

The capacity of transmitting the discipline knowledge builds on literacy and writing skills, which has been a matter of interest in higher education for decades [81-84]. The notable decay in writing skills among engineering students stems from the evolving transformation of the teaching-learning process. Indeed, contemporary undergraduate engineering students struggle to write a composition, a report, or an assignment while keeping a fair and logical structure and style. They even find difficulties with using the specific terminology of the discipline. The increasing use of digital media and, hence, taking less notes, as well as the evaluation features, have diverted the writing standards requirements for both instructors and learners [85]. So, it has become a matter of concern for institutions [48-50,86]. Altogether, and in accordance with ABET criteria, it appears mandatory to undertake actions so that undergraduate engineering students improve their functional writing skills. The persistence on assigning essays to students and challenges based on work groups has a beneficial impact on their writing skills $[35,87]$.

\subsection{Opportunities and Risks of Online Teaching}

\section{- $\quad$ Student engagement}

Cognitively involved students are prone to engaging rapidly with a desire to master the knowledge [88]. The individual's knowledge, attitude, and technical skills, such as computer literacy, self-directed learning, interaction in learning, and flexibility in content, foster positive behaviors to succeed in online learning [89].

More than a few studies highlight the impact of online education on higher education in fostering quality, and some of them show the beneficial role of social interaction on learning achievement, interaction behavior, barriers, capacity for interaction, and group interaction $[6,27,71]$.

Due to the closure of classrooms caused by the global pandemic in 2020, students had to undergo the remote learning experience and struggled to overcome the difficulties to follow the courses, often focusing their efforts on passing the module rather than having 
actual active learning experiences [90]. Learners had to give the best of themselves to develop technical learning skills towards success. Social interaction, understood as the exchange of verbal and nonverbal communication within the classroom environment that causes modification of actions, reactions, and relations among individuals, has proven to be an effective feature that contributes to active learning [71,91]. Nonetheless, the lack of social interaction has hindered learning achievements because of the sudden change to online teaching $[36,92]$.

\section{- Evaluation}

The evaluation relates concrete educational practices to the educational standards prescribed at the international or national level and is definitely associated with educational quality $[93,94]$. Evaluation represents the culmination of access to knowledge and assessment is an objective and quantifiable element that facilitates the judgement and comparison with classmates [95].

Contemporary higher education pedagogical models and their support through ICT media usually focus on quantitative and summative assessment. Current LMS comprise diverse types of questions oriented to quantitative evaluation, although multiple-choice tests are the most used. Other assessment technological approaches, such as gamification, CRS, and virtual reality, emerge as new possibilities. Nonetheless, ICT and new technologies demand new skills and digital competencies for all educational stakeholders $[30,96]$.

The authors agree that the evaluation process must also be an opportunity to measure communication and transmission skills $[11,22,30,31,85,90,94,95]$. Indeed, formative assessment is a valuable method to enhance student outcomes [97-100]. Nevertheless, this methodology must address three challenges: (1) how to effectively promote meaningful learning; (2) how to design grading schemes to promote the personal outcomes rather than competition; (3) assessment feedback may cause a negative impact on low-achieving students, who may become discouraged [97,98].

\section{Materials and Methods}

This research aims to examine the effect of the ICT-based flipped learning model carried out by the authors on some transversal students' competencies that are valued for professional careers.

A brief scheme of the implemented model is shown in Figure 1.

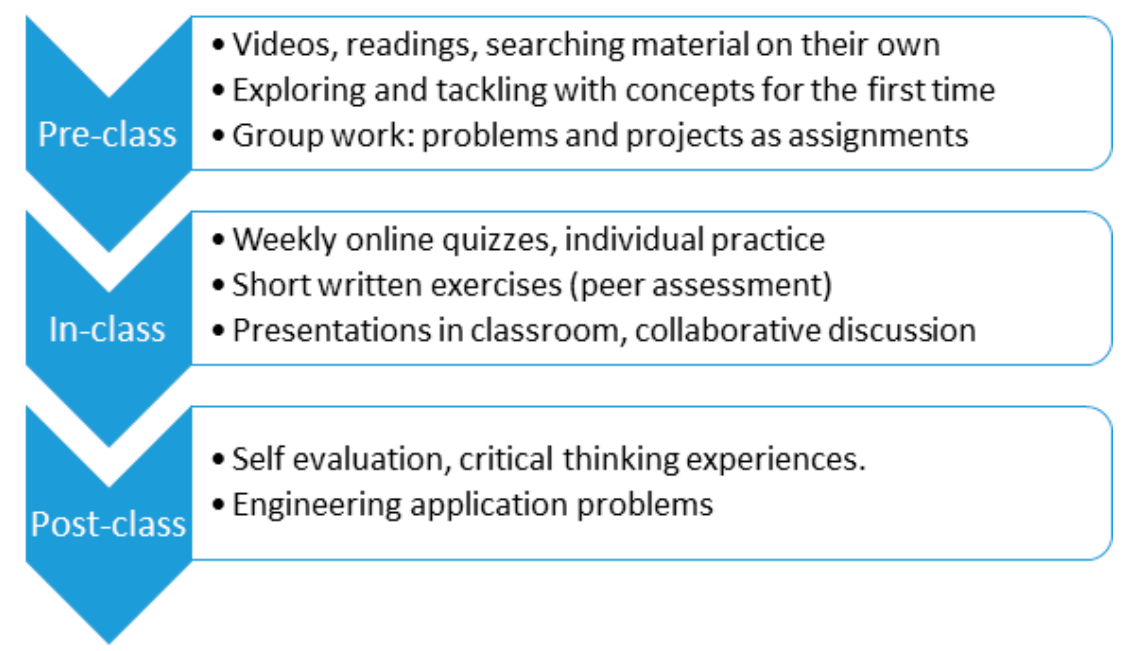

Figure 1. Elements of the flipped teaching model performed by the authors.

The study was conducted by using a mixed methodology divided into two phases. The first consisted of a systematic review of the reports, assignments, and exams delivered by students. From this review, the authors established trends of the two outcomes highlighted by ABET with respect to actors, purposes of assessment, fields of knowledge, 
educational levels, digital tools, and platforms in the second phase. This process has given an insight into the possibilities of the flipped learning approach performed by the authors for encouraging students to achieve both ABET prescribed outcomes.

The engineering semestral modules included in this study are Operations Research I and II (UDEP), Theory of Structures and Elasticity and Strength of Materials (UJA), Project Management (UPM), Geology Engineering (UPM), and Strength of Materials (UPM). All modules focus on a student-centered basis; their setup involves workgroup projectbased assignments except the latter, whose setup builds on weekly individual problem assignments to hand in before the next week's first-day class.

The modules included in this study focus on practical and professional skills that students need to attain.

The students were surveyed twice during the semester and invited to participate in either individual or group interviews.

The formal object encompasses the combination of web-based tools with other open educational resources (OER), which altogether contribute to enlarging the availability of the so-called e-textbooks [78], necessary for the blended learning models implemented at these teaching units.

\subsection{UPM}

The instructors organized the modules using visual guides so the first day of class became very useful to give an overall insight of the syllabus. The first day of class significance is not negligible, since it may influence several features, such as building students expectations, attitudes, engagement, or motivation. It is no wonder that many teaching books dedicate a chapter to the first day of class $[96,101]$.

Part of the lockdown first month classes were taught by means of pre-recorded videos during the 2019-2020 academic year (Figure 2). Such a task entailed an additional effort by instructors to achieve digital competencies to overcome the difficulties. Later, classes were given synchronously, albeit recorded as well, to facilitate students' self-directed learning. Upon the flipped teaching model, students were prompted to visualize videos and understand the principles of the module tenets. Teachers implemented this multimedia technology to provide students with learning materials and allow them to view and preview to learn autonomously without time or space constraints. Instructors also guided learners to gather information before class and prompted them to be owners of their own active learning. These teaching videos were intended to allow students to have some deep knowledge before class and to help those students who missed classes to catch up [11,40].

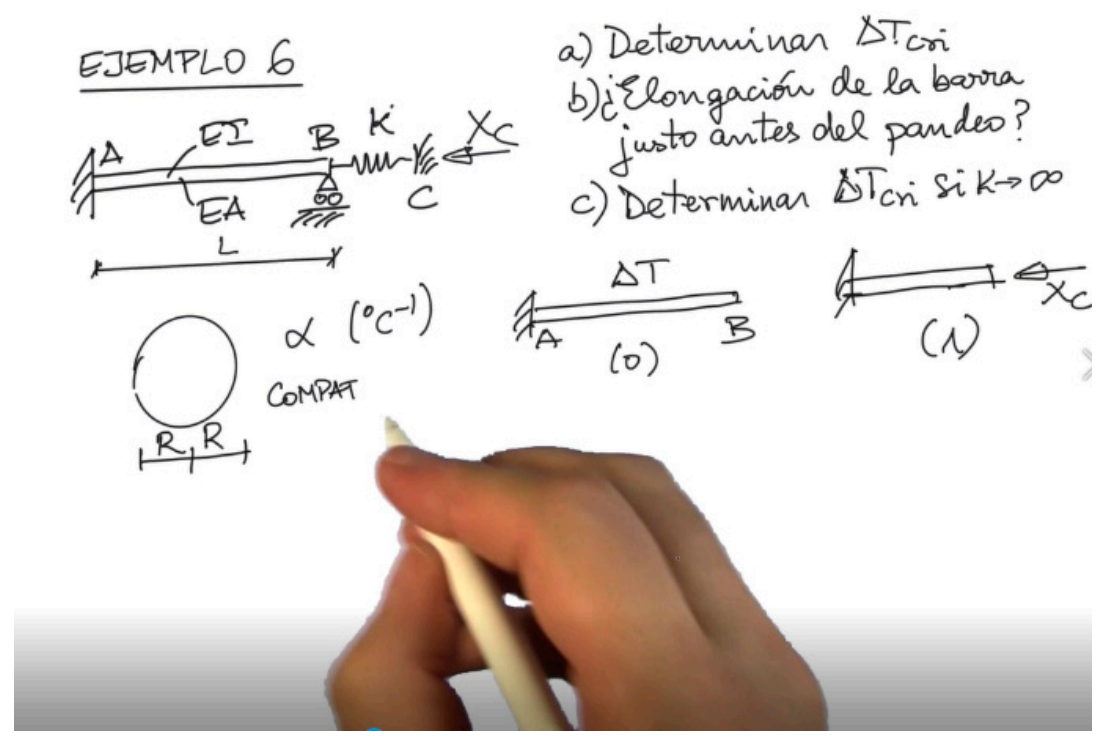

Figure 2. Snapshot from a pre-recorded video available to students for autonomous viewing. 
However, it was mandatory for instructors to follow up on students' accomplishments. Thus, in some cases, short questions inserted within the videos (Edpuzzle) required to be answered before users could continue watching. In other cases, instructors performed micro-activities during the next class to measure their learning effectiveness, so students had to respond to short exercises or quizzes at the beginning of the next class.

Instructors applied other activities to enhance students' motivation and engagement: weekly online quizzes and assignments, some of which consisted of essays, to follow up on their technical writing and communication skills as well as their capability of applying new knowledge. Weak communication skills showed up at this point. For instance, some fourth-year students encountered difficulties when describing the team staff and procedure for a construction project and even when highlighting the differences between the staff structure of a construction enterprise and that of a construction site. Yet around half of the second-year students were not able to distinguish between internal forces and stresses in a retaining wall. These weaknesses emerged during the weekly follow-up of students homework as well as in the evaluation. This study has identified various causes: low concept level, poor comprehension reading, low attention and readiness, weak attitude, and low writing and communication skills.

Classes were hybrid and synchronous during the 2020-2021 academic year, so students could choose between attending in person and following classes remotely. Instructors kept the same flipped teaching mode as in the previous online 2019-2020 academic year. However, instructors intensified the problem-based learning supported by weekly assignments with problems solved by the teacher later the next week. Exams also focused slightly more on the practical applications of knowledge and required more wording content from students when compared with previous years.

The students used to visit job sites during construction and maintenance stages. However, such visits were substituted by videos. This alternative can have certain advantages as it can provide deeper and wider information. However, after two academic years of experience, the advantages of present visit are clearer than ever. The contact with reality significantly increases motivation, retrieval practice and interest, which boosts their learning experience, especially long-life learning achievement.

\subsection{UJA}

Since March 2020 the education in the Spanish university has been hybrid, which means that some students are present in the classroom while others follow classes by synchronous online teaching, although exclusive online teaching has been mandatory for some months. This has triggered the use of flipped teaching during the 2020-2021 academic year in at least two modules: Theory of Structures (3rd year of the Mechanical Engineering degree) and Theory of Structures (2nd year of the Civil Engineering degree). It must be noted that, despite both modules having the same name, the contents are completely different. While the module taught in Mechanical Engineering covers calculation methods of pinned and framed structures, such as the Cross method and matrix structural analysis, the one taught in Civil Engineering covers an introduction to elasticity and strength of materials.

In order to cope with online learning, some strategies based on flipped teaching have been used to motivate students; the experience at the end of the 2019-2020 academic year, when pandemic restrictions started, suggested that students' motivation was a key factor for their engagement and, thus, for their academic success.

On the one hand, the use of web-based parameterized problems was selected to encourage students to reason and think of structural behavior, which helps in understanding key structural concepts [102]. A parameterized problem was proposed at the end of a class, including some questions to analyze by means of a web-based problem that allowed students to modify parameters and observe their influence on the structural response. After their autonomous work at home, the first part of the next class was devoted to discussing and sharing their findings with the teacher's guidance. 
On the other hand, part of the final mark (20\%) resulted from short problems to be solved in class. These problems were proposed with no previous notice, but always after the corresponding topic had been sufficiently covered in class. This technique was designed to motivate students in daily work, which is considered extremely important in these modules, where contents are supported by each other.

\subsection{UDEP}

The social isolation measures due to COVID-19 occurred in Peru at the very beginning of semester I of 2020. Since then, the Faculty of Engineering of Universidad de Piura has been teaching classes virtually. Teachers had to adapt their modules to use new technologies, new teaching tools and methodologies, new assessment systems, make use of simulators, workshops or virtual laboratories, etc., in order to achieve the learning objectives in a teaching environment unknown to most teachers and students, seeking at all times to maintain quality in teaching. The flipped classroom model, changing the students role so that they take ownership of their learning, suffered the least across the adaptation to online teaching [11,102]. In the Operations Research module, classes were taught in both synchronous and asynchronous modes. Instructors had to create pre-recorded videos, which helped students to better internalize the concepts. Other tasks were: (1) readings, that were evaluated before starting the class; (2) challenge-based assignments to find solution proposals to given cases from their most personal scope; (3) exercises to be solved in groups as collaborative learning. As a result, the students built their experiential learning and developed the ability to apply new knowledge through teamwork and leadership, which also improved motivation and commitment. However, instructors have found difficulties in communication competencies, indispensable for engineering training. Another detected difficulty was comprehension reading, understanding what is asked in a statement, and not discriminating what is important. Poor written expressiveness reflected by poor writing and spelling mistakes, as well as poor penmanship. One of the reasons is due to the immediacy of access to information, derived from the use of the internet and mobile phones, which does not allow students to reflect, due to the amount of information received [76,81]. Instructors have identified the type of mistakes; the majority are due to not reading the statements well and not responding adequately to what is requested and, in some cases, not understanding what they write, clear evidence that we are not contributing to this competition. Even graduate students are highly valued in technical skills by employers, with weaknesses in soft skills, especially low in assertive communication competence.

\section{Results}

\subsection{Students' Use and Perception of Videos and Other Flipped Learning Materials}

This study draws on the analytics of use of the LMS and the number of accesses to the videos delivered to students on YouTube and other platforms. Figures indicate that students regularly used both sources throughout the semester for continuous evaluation in most cases, whereas they tended to access the most the day before the end-of-year exam.

The number of accesses to the pre-recorded videos shows remarkable differences between theoretical ones and solved-problem videos. For instance, regarding the videos available in the YouTube playlist belonging to the module Strength of Materials https: / / www.youtube.com/playlist?list=PL8bSwVy8_IcP4j_uOLgNiZtdIvClY2ydn (accessed on 27 September 2021).

Table 1 details the number of views of a series of videos related to the core content of Strength of Materials. Being a sequential list in accordance with the syllabus, some videos concerning specific technological applications, but seldom asked in exams, were the least watched or lowest number of accesses (98 and 124), whereas the videos related to the content usually asked in the regular exams were the most visited. 
Table 1. Number of views of a series of pre-recorded videos used in the module Strength of Materials during the last academic year 2020-2021.

\begin{tabular}{cccc}
\hline \multicolumn{2}{c}{ Theoretical Videos } & \multicolumn{2}{c}{ Solved-Problem Videos } \\
\hline Section & Number of Visits & Section & Number of Visits \\
\hline 5.1 and 5.2 & 398 & 4.5 & 525 \\
\hline 5.3 & 328 & 5.3 .1 & 332 \\
\hline 5.4 & 886 & 5.3 .2 & 256 \\
\hline & & 5.4 .1 & 486 \\
\hline & & 5.4 .2 & 1935 \\
\hline & & 5.4 .3 & 677 \\
\hline & 5.4 .4 & 589 \\
\hline & 5.5 & 98 \\
\hline
\end{tabular}

Analytics show that most of the module materials are accessed just two or three days before the exam.

Table 2 shows the figures of passing students versus the number of enrolled students, which implies the number of attempts to sit the exams.

Table 2. Numbers related to the enrolled students and passing figures during three academic years: 2018-2019 (on-site)/2019-2020 (online)/2020-2021 (hybrid and enhanced proactive assignments).

\begin{tabular}{cccc}
\hline Registrations & No. of Enrolled Students & No. of Passing Students & Success Rate (\%) \\
\hline Once & $88 / 86 / 89$ & $10 / 23 / 27$ & $11.3 / 26.7 / 30.3$ \\
Twice & $81 / 65 / 71$ & $27 / 30 / 35$ & $33.3 / 46.0 / 49.2$ \\
Three or more & $57 / 54 / 65$ & $11 / 20 / 25$ & $19.3 / 37.0 / 38.4$ \\
Aggregate & $226 / 205 / 225$ & $48 / 73 / 87$ & $21.2 / 35.6 / 38.6$ \\
\hline
\end{tabular}

Number of registered students: 226 (2018-2019 academic year), 205 (2019-2020 academic year), 225 (2020-2021 academic year).

Instructors conducted voluntary and anonymous surveys among students as well as personal interviews to gather information about their perceptions and outcomes. Results are expressed in Likert format, ranging between 1 (highly disagree) and 5 (strong agreement). A summary of results for 54 respondents are shown in Table 3.

Table 3. Students' perceptions on impartations, resources available, outcomes and achievement.

\begin{tabular}{|c|c|c|c|c|c|c|c|}
\hline How Do You Value? & $\begin{array}{l}\text { (5) Strongly } \\
\text { Agree }\end{array}$ & (4) & (3) & (2) & $\begin{array}{l}\text { (1) Strongly } \\
\text { Disagree }\end{array}$ & Mean & $\begin{array}{l}\text { Std } \\
\text { Dev }\end{array}$ \\
\hline That the recent exams became easy? & $0 \%$ & $6.8 \%$ & $43.2 \%$ & $38.6 \%$ & $11.4 \%$ & 2.45 & 1.32 \\
\hline The adequacy of exams to the module syllabus? & $20 \%$ & $48.9 \%$ & $22.2 \%$ & $8.9 \%$ & $0 \%$ & 3.80 & 1.31 \\
\hline Your preference about onsite exams vs online & $37.8 \%$ & $33.3 \%$ & $11.1 \%$ & $13.3 \%$ & $4.4 \%$ & 3.87 & 1.62 \\
\hline $\begin{array}{l}\text { The usefulness of CRS on your learning } \\
\text { achievements? }\end{array}$ & $13.6 \%$ & $36.4 \%$ & $25.0 \%$ & $13.6 \%$ & $11.4 \%$ & 3.27 & 1.71 \\
\hline $\begin{array}{l}\text { The usefulness of LMS on your self-paced } \\
\text { learning and learning achievements? }\end{array}$ & $4.7 \%$ & $51.2 \%$ & $18.6 \%$ & $20.9 \%$ & $4.7 \%$ & 3.30 & 1.52 \\
\hline $\begin{array}{l}\text { Your PBL learning achievement during the } \\
\text { pandemic? }\end{array}$ & $17.3 \%$ & $28.8 \%$ & $34.6 \%$ & $17.3 \%$ & $1.9 \%$ & 3.42 & 1.57 \\
\hline $\begin{array}{l}\text { Your degree of satisfaction with the e-resources } \\
\text { delivered by the instructors of the module } \\
\text { during the lockdown period? }\end{array}$ & $36.5 \%$ & $36.5 \%$ & $23.1 \%$ & $3.8 \%$ & $0 \%$ & 4.06 & 1.29 \\
\hline $\begin{array}{l}\text { Your certainty on having mastered the key } \\
\text { concepts taught in the module? }\end{array}$ & $11.5 \%$ & $36.5 \%$ & $42.3 \%$ & $9.6 \%$ & $0 \%$ & 3.50 & 1.38 \\
\hline
\end{tabular}


Table 3. Cont.

\begin{tabular}{|c|c|c|c|c|c|c|c|}
\hline How Do You Value? & $\begin{array}{l}\text { (5) Strongly } \\
\text { Agree }\end{array}$ & (4) & (3) & (2) & $\begin{array}{l}\text { (1) Strongly } \\
\text { Disagree }\end{array}$ & Mean & $\begin{array}{l}\text { Std } \\
\text { Dev }\end{array}$ \\
\hline $\begin{array}{l}\text { The amount of learning digital material available } \\
\text { for learning during this course? }\end{array}$ & $56.5 \%$ & $43.5 \%$ & $0.0 \%$ & $0.0 \%$ & $0.0 \%$ & 4.57 & 0.50 \\
\hline $\begin{array}{l}\text { The quality of learning digital material available } \\
\text { for learning during this course? }\end{array}$ & $43.5 \%$ & $34.8 \%$ & $8.7 \%$ & $13.0 \%$ & $0.0 \%$ & 4.09 & 1.41 \\
\hline The instructor's module mastery? & $82.6 \%$ & $13.0 \%$ & $4.3 \%$ & $0.0 \%$ & $0.0 \%$ & 4.78 & 0.67 \\
\hline The instructor's clarity when teaching? & $65.2 \%$ & $26.1 \%$ & $8.7 \%$ & $0.0 \%$ & $0.0 \%$ & 4.57 & 0.88 \\
\hline $\begin{array}{l}\text { The ambiance, communication and relationship } \\
\text { with your classmates in this module? }\end{array}$ & $39.1 \%$ & $34.8 \%$ & $26.1 \%$ & $0.0 \%$ & $0.0 \%$ & 4.13 & 1.22 \\
\hline $\begin{array}{l}\text { The communication and relationship with your } \\
\text { instructors of this module? }\end{array}$ & $47.8 \%$ & $39.1 \%$ & $13.0 \%$ & $0.0 \%$ & $0.0 \%$ & 4.35 & 0.98 \\
\hline $\begin{array}{l}\text { Your initial readiness and knowledge of } \\
\text { fundamentals of this module? }\end{array}$ & $8.7 \%$ & $21.7 \%$ & $43.5 \%$ & $8.7 \%$ & $17.4 \%$ & 2.96 & 1.69 \\
\hline $\begin{array}{l}\text { The learning effort you have performed in this } \\
\text { module? }\end{array}$ & $26.1 \%$ & $52.2 \%$ & $17.4 \%$ & $0.0 \%$ & $4.3 \%$ & 3.96 & 1.28 \\
\hline $\begin{array}{l}\text { The knowledge outcome you have reached in } \\
\text { this module? }\end{array}$ & $26.1 \%$ & $52.2 \%$ & $17.4 \%$ & $4.3 \%$ & $0.0 \%$ & 4.00 & 1.16 \\
\hline $\begin{array}{l}\text { The fulfilment extent of the learning } \\
\text { expectations you have reached? }\end{array}$ & $34.8 \%$ & $43.5 \%$ & $13.0 \%$ & $8.7 \%$ & $0.0 \%$ & 4.04 & 1.29 \\
\hline $\begin{array}{l}\text { Your degree of satisfaction with your individual } \\
\text { engagement in this module? }\end{array}$ & $17.4 \%$ & $52.2 \%$ & $17.4 \%$ & $8.7 \%$ & $4.3 \%$ & 3.70 & 1.44 \\
\hline $\begin{array}{l}\text { The overall performance of the instructors of this } \\
\text { module during this semester? }\end{array}$ & $65.2 \%$ & $26.1 \%$ & $8.7 \%$ & $0.0 \%$ & $0.0 \%$ & 4.57 & 0.88 \\
\hline
\end{tabular}

\subsection{Students' Engagement with the Modules}

In the case of the two modules taught at UJA, Theory of Structures and Elasticity and Strength of Materials, results were irregular, as can be observed in Figure 3. This figure shows the evolution of the two main assessment tools used in these modules: assignments and a final exam. While results of the module taught in the 3rd year of Mechanical Engineering (Figure 3a) were similar in the whole series of academic years, the results of the module taught in the 2nd year of Civil Engineering (Figure 3b) clearly decreased in the two academic years affected by the COVID-19 pandemic. It must be noted that, traditionally, students in the module of Mechanical Engineering (first group) are very much engaged with the learning process, maybe because they find it appealing and useful for their future professional performance, maybe because they are in their 3rd year and are more concerned with their learning process, or maybe a combination of both. On the contrary, students in the module of Civil Engineering (second group) traditionally show a much lower engagement, which has been accentuated by the online and hybrid teaching as Figure $4 \mathrm{~b}$ suggests. The use of web-based parameterized problems was found helpful in the first group, since it stimulated a rich discussion motivated by their own experience with the online tool designed for this activity. Some students in the second group followed this activity, but many of them showed scarce interest and did not work at home with the problems proposed.

Writing skills are mainly practiced by means of five assignments proposed along the semester for two-student groups and consist of solving a problem with concepts and methods taught in class and with specific software, such as MATLAB or Robot Structural Analysis. The students must produce five final reports, one per assignment, which is evaluated considering not only the results and a correct resolution, but also the quality of the reports (good quality figures and good writing). It is interesting to observe how online teaching did not affect either the final exam or the assignments scores in the case of the first group, while both scores were considerably reduced in the second group.

Figure 4 compares the correlation between assignments' average scores and the final exam score of all the students through the last five academic years with linear trend lines, 
which intend to help in understanding the differences between the last two years, affected by the COVID-19 pandemic, and the previous three.

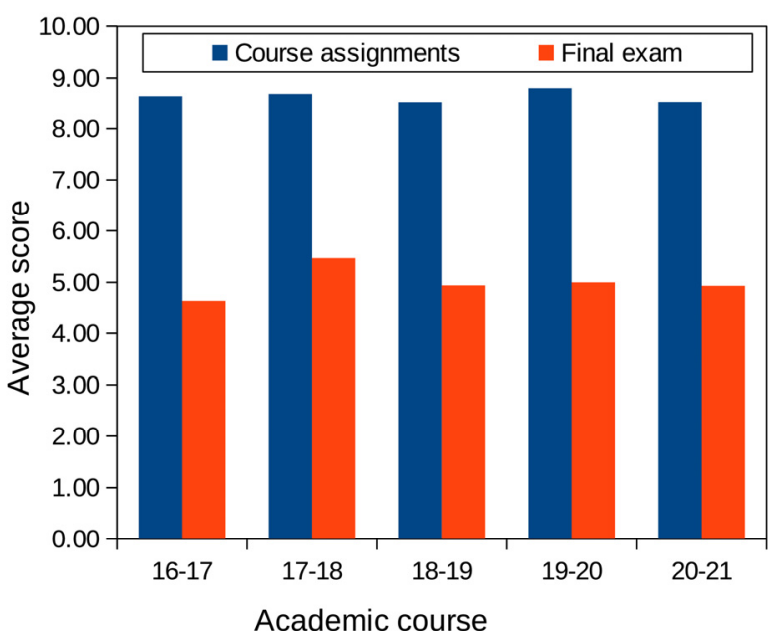

(a)

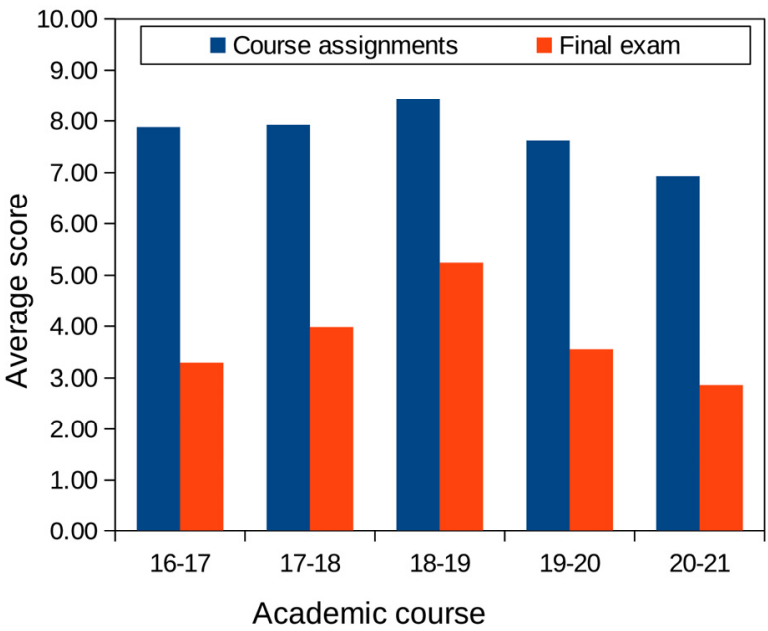

(b)

Figure 3. Evolution of average marks in the assignments and the final exam during the last five academic years in both modules taught in Universidad de Jaén (UJA): (a) Theory of structures of the 3rd year of Mech. Eng.; (b) Theory of structures of the 2nd year of Civil Eng. Grades range between 0 (worst grade) and 10 (best grade).

In the case of the first group (Figure 4a), the trend is very similar in all five academic years. In every academic year, points tend to gather around the linear trend lines, depicted with dashed lines and with an increasing slope, which suggests that the higher the score in the assignments, the better the final exam score. These results, which correspond to a group of students that have traditionally shown a high engagement with the module, as well as with the assignments proposed during the term, suggest that when the students are motivated, there is a high correlation between the score obtained in the assignments and the score obtained in the final exam. The assignments of these students have always been of a general high quality, as can be observed in Figure 4a.

In the case of the second group (Figure $4 \mathrm{~b}$ ), although all trend lines have positive slopes, as in the case of the first group, points are scattered around the trend lines and less concentrated around them. These results suggest that the correlation between the scores obtained in the assignments and in the final exam is not clear. As shown in the figure, some students obtained a high score in the final exam although their performance in the 
assignments was mediocre, while some others obtained bad results in the final exam after performing well in the assignments.

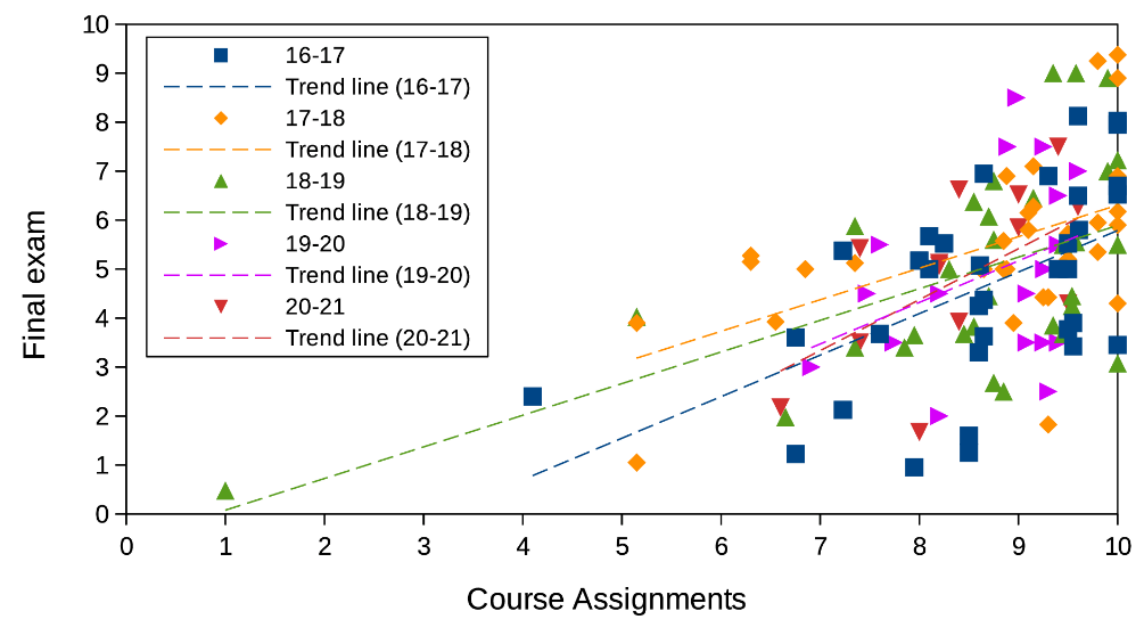

(a)

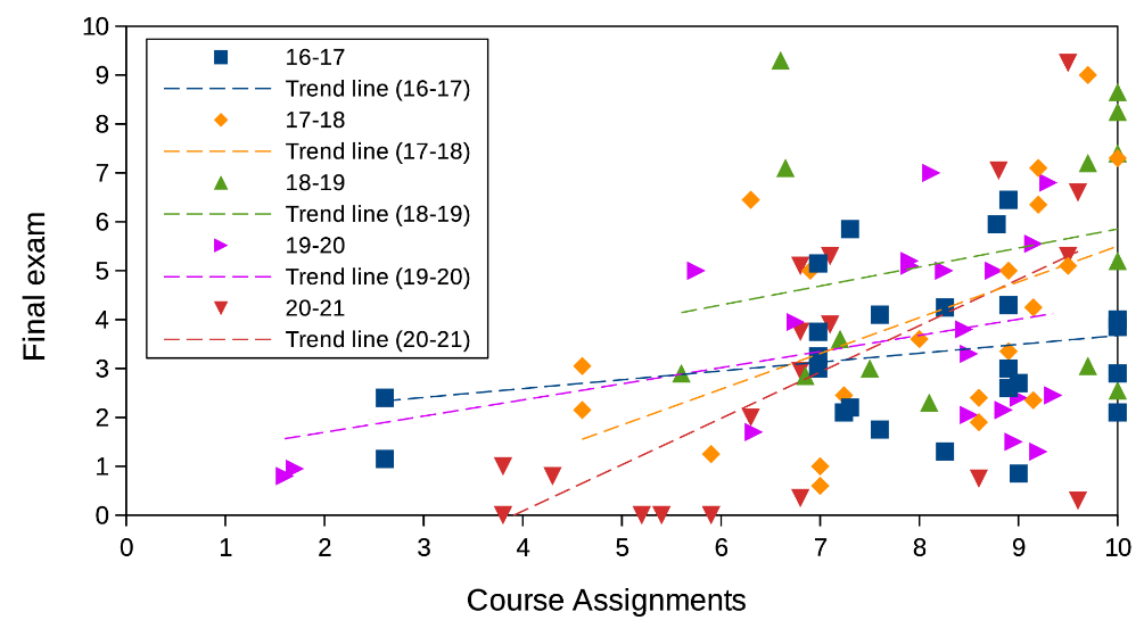

(b)

Figure 4. Correlation of assignment average score and final exam score through the last five academic years in both modules taught at Universidad de Jaén (UJA): (a) Theory of structures of the 3rd year of Mech. Eng.; (b) Theory of structures of the 2nd year of Civil Eng.

These results confirm that students' engagement is a key factor for good final results. When the students are engaged, online teaching and flipped learning is effective and the daily work, evidenced by the assignment scores, is of good quality. Nevertheless, when the group is not motivated, their low engagement makes flipped learning ineffective, which explains why the assignments do not reflect clearly the true building of knowledge of the students.

\subsection{Students' Performance in Writing}

Communication in engineering is essential and only engineers themselves can perform technical communications, so they must care for their integrity. Then, undergraduate students must keep rigor with the use of discipline-specific terms and ideas, which requires reorganizing thoughts, style, clarity, and conciseness. Scientific research and innovation build on well-expressed knowledge. Scientific writing is regarded as a tool that conditions the ways of understanding and interpreting the world. However, few institutional experiences promote the development of professional writing in the undergraduate engineering 
instruction. Results obtained after the final evaluation of a third-year engineering module at Universidad de Piura, during two remote-teaching courses, have been evaluated and can be observed in Table 4 . These results show that a third of those who failed in the evaluation were the result of comprehension reading and communication errors: failing students did not answer what was asked or did not base their answers correctly on the results obtained. One reason may be their immediate access to information using digital devices, which deprives them of reflecting due to the amount of information available. Table 4 shows the percentage of failures in the final evaluation of the module due to errors in solving problems that resulted from their low communication skills.

Table 4. Final written and compulsory exam weighing $30 \%$ of the module.

\begin{tabular}{cccc}
\hline Semester & 2020-I & 2020-II & 2021-I \\
\hline Number of students & 150 & 152 & 123 \\
\% Failing students & $30 \%$ & $30 \%$ & $27 \%$ \\
$\%$ Communication mistakes & $42 \%$ & $35 \%$ & $33 \%$ \\
\hline
\end{tabular}

The increased writing load for students implemented during the last academic year has enabled us to identify their scarce functional writing skills.

Both social interaction and increased tutorial activity can explain the increase in the passing figures and rate of success for the hybrid-mode academic year 2020-2021. At the same time, such a follow-up of learners showed a lack in their writing skills, not only in assignments but also in exams.

Figure 5 shows some excerpts from students' written exams, which resemble a childwriting typeface.

4.- Definir el concepto de nùcleo central de una sección y expresar cual es sú propledad pritucipul. [2 puntos]

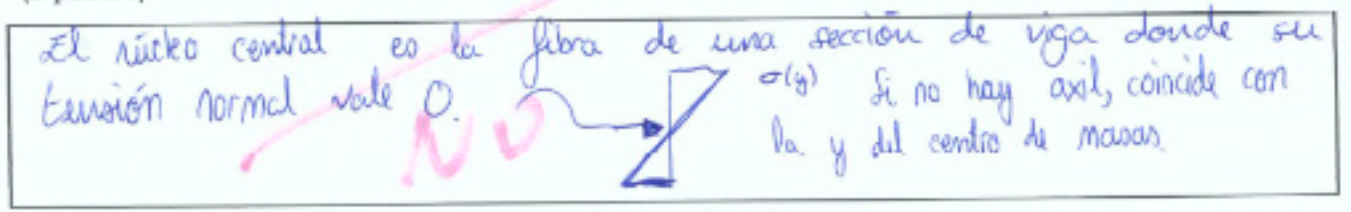

1) Define the concepts of response spectra of an earthquake and write their corresponding equations (1 point)

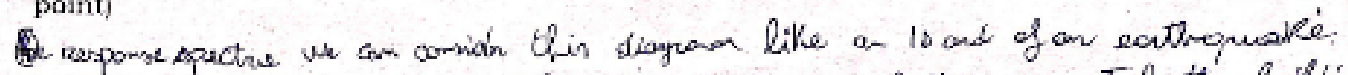

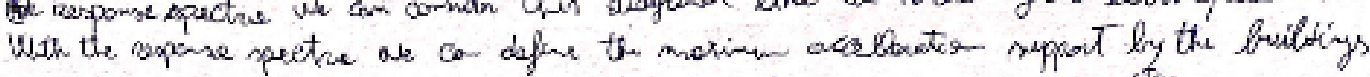
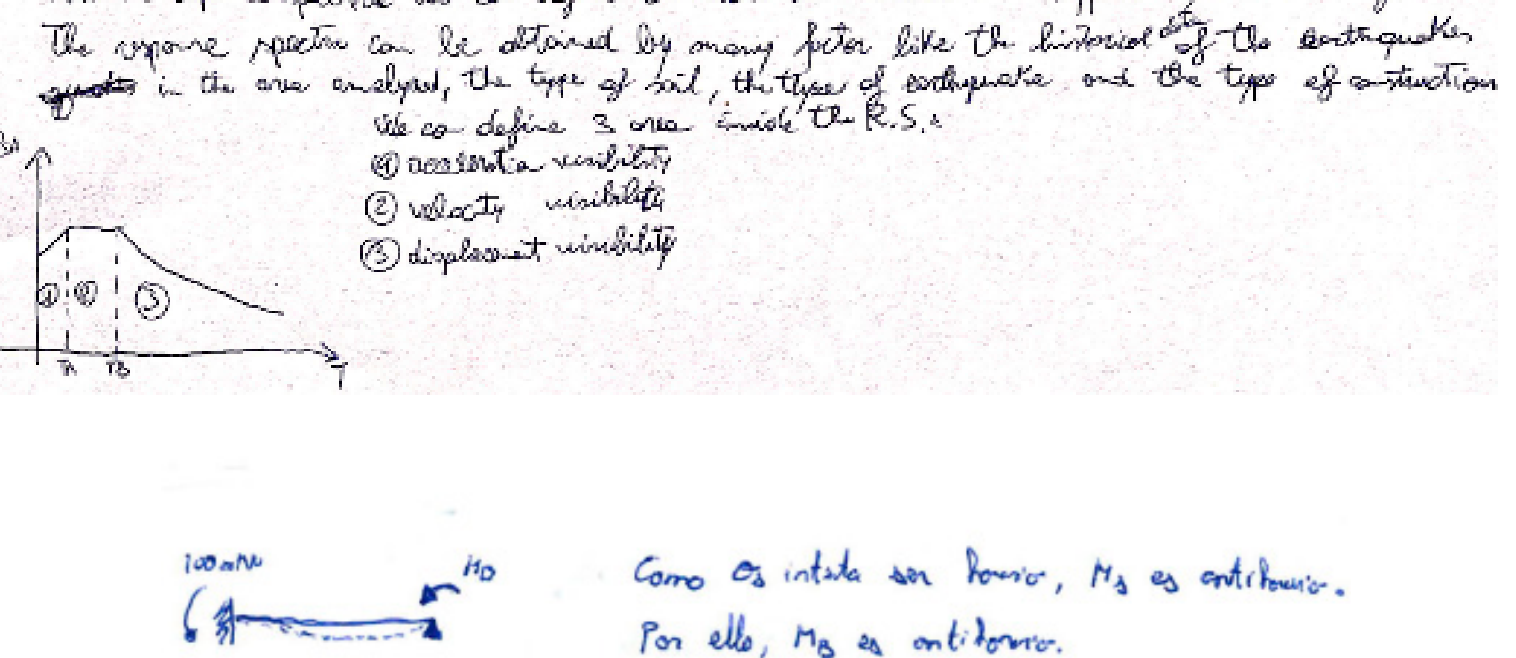

$$
\begin{aligned}
& \text { Como os intista ser hovios, } M_{3} \text { es entifouico. } \\
& \text { Pon ello, } M_{B} \text { as ontitorio. }
\end{aligned}
$$

Figure 5. Three excerpts from exams showing a writing style that need to be improved for university students. 


\section{Discussion}

Despite their drawbacks, traditional teaching methods still perform well with given disciplines, teaching situations, and students. In addition, the widespread use of digital resources in education and web-based tools in the teaching-learning process does not minimize the significance of traditional teaching environments but may enhance their effectiveness. Flipped classrooms have entailed a step ahead in shifting instruction toward a learner-centered teaching strategy. Indeed, computer-based learning (CBL) and webbased learning (WBL) maximize students' involvement and engagement [35,102], which is crucial for flipped learning techniques to be effective and to boost students' motivation, which, as suggested by results shown in Figures 3 and 4, has a strong relation with their overall performance (Mechanical Engineering students showed high motivation and these techniques proved to be effective while Civil Engineering students showed low motivation and their results were poorer).

The move to online teaching due to the closure of classrooms caused by the 2020 global pandemic has shed light on some instructional actions and approaches that deserve a debate. Some features of remote teaching and digital resources have arrived and are expected to remain [103]. Because of the digital profile and study habits of contemporary university students, the availability of pervasive digital media, and the relevance of digital resources, it seems reasonable to value reducing the cognitive load in favor of amplifying the core concepts and competencies of each discipline, boosting engagement strategies $[7,20,88]$ and rethinking the evaluation $[18,31,103,104]$.

Selecting the core concepts of the discipline is paramount to ensure that students can reach the expected knowledge outcomes and skills. Such a selection involves identifying which material may be causing distraction, confusion, or complexity for students and organizing the material and resources available so that they can navigate through the LMS accordingly. Activities that introduce new material to students imply a first contact with new concepts. Flipped teaching puts the spotlight on this regard. Core concepts allow chunking of the module content into units, although they are often connected to each other. Instructors should remind students when core concepts connect diverse module units, so the latter can understand the relationship of core concepts within module materials.

Besides, instructors must guide students through their pathway to show them how to achieve the specific competencies through an itinerary based on the learning outcomes [104]. Hence, problem-based learning and project-based learning have proven good approaches in engineering education [87]. For instance, the concept of stress is essential in Strength of Materials. A learning outcome may be how to design a footing so that the acting stresses on the ground are lower than a limit value. Nevertheless, the stresses are also related to the design of other structural elements such as cantilevers, beams or columns. The competencies involved in this case could be analysis, evaluation, and creation. They seek that the learners improve their critical thinking, spatial reasoning, arguing skills and the ability to demonstrate. In this regard, the PBL technique is complementary to the conceivedesign-implement-operate (CDIO) model [105]. Nurturing higher-order thinking capability is a major goal of some recent curricula redesigns and it is crucial for a knowledge-based society [106-110].

Regarding content delivery, teaching the engineering students of the 21st century should not use the methods of the 20th, so instructors should avoid long, synchronous lectures. Instead, it is time to uphold quality time spent with students to emphasize the main principles or concepts, clarify common misconceptions in the module, and expectations for upcoming assignments. A number of instructors propose that moving from contentcoverage to learner-centered approaches will help students better read and learn, retain knowledge, and apply it to new situations in accordance with ABET criteria $[17,18,23]$, which, as evidenced by results shown in Table 4, is an important aspect for current engineering students to improve.

While lectures are necessary and help in keeping a good pace at covering the essential contents of the course, it may also be convenient to select multimedia sources such as online 
videos, tutorials, or concise articles that will help convey content rather than assigning lengthy or dense readings. Thus, short videos with minilectures and recap videos to ease cognitive load and scaffolding student learning may be useful [24]. Students' perceptions of these innovative techniques, such as CRS and LMS, is generally good, as suggested by the survey results shown in Table 3. Nonetheless, watching videos is not enough; students must practice comprehension reading and carry out application actions, which instructors must follow to assess those outcomes necessary for the professional career.

The two evidence-based learner-centered strategies presented here are based on the flipped teaching model and aim at enhancing engineering students' motivation towards acquiring transmission and communication skills: problem-based learning and teamwork assignments. These strategies can encourage students to learn better, comprehend, apply, and transmit a module's core concepts to new situations [72]. In any case, students' engagement is of paramount importance in order to achieve effective learning; otherwise, students can perceive these strategies as non-core activities with a smaller importance in the module. This would entail students failing in both learning outcomes highlighted in this study, i.e., functional writing and communication skills. The authors hold that flipped teaching is a feasible way to implement proactive instruction techniques whenever it emphasizes the importance of student writing through appropriate writing assignments and exams. Likewise, a fair evaluation still needs exams and strict evaluation standards other than multiple-choice quizzes or online tests. Conversely, it seems mandatory that students show their functional writing skills to demonstrate the outcomes prescribed by ABET for engineering students: the ability to communicate effectively with a range of audiences and the ability to acquire and apply new knowledge as needed, using appropriate learning strategies.

\section{Conclusions}

Flipped teaching is a widely accepted methodology that implies a shift to a learnercentered setting is open to a multipurpose teaching framework and may encompass a variety of outcomes. It seems that flipped learning has proven to be effective. However, it is relevant to understand that there are contents more likely to be applied in a virtual environment than others are. Hence, constant research and further debate are required, not only about the approaches but also the strategies to address them.

This study proposes two evidence-based strategies based on the flipped teaching model that instructors can adopt to enhance the motivation of engineering students toward acquiring transmission and communication skills: problem-based learning and teamwork assignments.

The main conclusions of this study can be summarized as follows:

- $\quad$ Flipped teaching should not be limited to preparing videos, since the pure watching activity hinders the achievement of various outcomes in case there are no other activities to guide and engage students, such as achieving critical thinking and other higher-order thinking skills-in accordance with Bloom's taxonomy: application, analysis, synthesis and evaluation.

- Some outcomes may have been losing the spotlight: the comprehension reading and the functional writing skills, which are the cornerstones of the outcomes prescribed by ABET for engineering students, the ability to communicate effectively with a range of audiences, and the ability to acquire and apply new knowledge as needed, using appropriate learning strategies.

- Student engagement is crucial for a good performance of flipped learning techniques. When the students are motivated and engaged with the learning process, their daily work is of better quality and, if the flipped learning techniques include writing and comprehension skills, these skills are trained and improved.

- The experience has shown that students that had completed almost the whole degree (four years) with in-person classes, could shift to an online system with relatively 
good performance, although they were not used to those formats. Indeed, such a change even increased their digital skills.

- On the contrary, those students that have performed their recent studies on virtual supports face what could be named as ICT-tiredness (Information and Communications Technology). Moreover, this has deepened the lack of vocabulary and reading skills produced by the new supports, such as Twitter or WhatsApp, getting them used to short, fast, and very simple messages.

- These learner-centered strategies can help students to learn better, comprehend, apply, and transmit a module's core tenets to new situations.

- Organizing the module using a visual guide is a beneficial practice for interacting with students and clarifying expectations. Chunking the syllabus content into units reduces cognitive load in favor of emphasizing the core concepts that students need to apply in their professional careers.

Flipped teaching approaches in engineering should emphasize the importance of literacy writing through suitable writing assignments and strict evaluation standards. Instructors are bound to teach students to complete a report, an essay, or an assignment with their own structure and objectives. Nonetheless, boosting functional writing skills and comprehension reading requires the commitment of the institutions to implement proactive instruction techniques to students. It is actually a pending task, even from an ethical and holistic perspective. Higher education in engineering should overcome these problems with strategies which make best use of instruction approaches, such as flipped teaching. This involves not reducing teaching strategies to delivering videos with a short presentation in class.

Author Contributions: Conceptualization, F.S. and J.C.M.F.; methodology, F.S., I.C., M.G.A. and J.C.M.F.; validation, J.C.M.F., F.S., I.C. and M.G.A.; formal analysis, J.C.M.F., F.S., I.C. and M.G.A.; investigation, F.S., I.C., M.G.A. and J.C.M.F.; resources, M.G.A. and I.C.; data curation, F.S. and I.C.; writing—original draft preparation, F.S. and J.C.M.F.; writing—review and editing, J.C.M.F., F.S., I.C. and M.G.A.; visualization, F.S., I.C., M.G.A. and J.C.M.F.; supervision, M.G.A. and I.C.; project administration, M.G.A. and F.S.; funding acquisition, F.S. and J.C.M.F. All authors have read and agreed to the published version of the manuscript.

Funding: This research was funded by Universidad de Jaén through the Educational Innovative Project PIMED06_201921 and by Universidad Politécnica de Madrid through the Educational Innovative Programme 2019-2020, Project codes IE1920-0405 and IE1920-0406.

Institutional Review Board Statement: Not applicable.

Informed Consent Statement: Not applicable.

Data Availability Statement: The data presented in this study are available from the authors upon request.

Conflicts of Interest: The authors declare no conflict of interest.

\section{References}

1. Bozhko, Y.V.; Maksimkin, A.I.; Baryshev, G.K.; Voronin, A.I.; Kondratyeva, A.S. Digital transformation as the key to synthesis of educational and innovation process in the research university. In Proceedings of the International Conference on Digital Transformation and Global Society, St. Petersburg, Russia, 22-24 June 2016; pp. 386-391. [CrossRef]

2. Faria, J.A.; Nóvoa, H. Digital transformation at the University of Porto. In International Conference on Exploring Services Science; Springer: Cham, Switzerland, 2017; pp. 295-308. [CrossRef]

3. Gaivoronskii, D.V.; Kutuzov, V.M.; Minina, A.A. Digital transformation of engineering education. In Proceedings of the 2017 IEEE VI Forum Strategic Partnership of Universities and Enterprises of Hi-Tech Branches (Science. Education. Innovations) (SPUE), St. Petersburg, Russia, 15-17 November 2017; pp. 3-6.

4. Safiullin, M.R.; Akhmetshin, E.M. Digital transformation of a university as a factor of ensuring its competitiveness. Int. J. Eng. Adv. Technol. 2019, 9, 7387-7390.

5. Santos, H.; Batista, J.; Marques, R.P. Digital transformation in higher education: The use of communication technologies by students. Procedia Comput. Sci. 2019, 164, 123-130. [CrossRef] 
6. Henderson, M.; Selwyn, N.; Aston, R. What works and why? Student perceptions of "useful" digital technology in university teaching and learning. Stud. High. Educ. 2017, 42, 1567-1579. [CrossRef]

7. Bond, M.; Buntins, K.; Bedenlier, S.; Zawacki-Richter, O.; Kerres, M. Mapping research in student engagement and educational technology in higher education: A systematic evidence map. Int. J. Educ. Technol. High. Educ. 2020, 17, 2. [CrossRef]

8. Ayinla, K.O.; Adamu, Z. Bridging the digital divide gap in BIM technology adoption. Eng. Constr. Archit. Manag. 2018, 25, 1398-1416. [CrossRef]

9. Coello, J.G.; Salazar, J.T.; Taborda, M.L.N. Peruvian students in pandemic: Digital gap and what is done from engineering programs? In Proceedings of the 2020 IEEE International Symposium on Accreditation of Engineering and Computing Education (ICACIT), Arequipa, Peru, 5-6 November 2020; pp. 1-4.

10. Rodríguez-Abitia, G.; Martínez-Pérez, S.; Ramirez-Montoya, M.S.; Lopez-Caudana, E. Digital Gap in Universities and Challenges for Quality Education: A Diagnostic Study in Mexico and Spain. Sustainability 2020, 12, 9069. [CrossRef]

11. García-Alberti, M.; Suárez, F.; Chiyón, I.; Mosquera Feijoo, J.C. Challenges and Experiences of Online Evaluation in Courses of Civil Engineering during the Lockdown Learning Due to the COVID-19 Pandemic. Educ. Sci. 2021, 11, 59. [CrossRef]

12. Mason, G.; Williams, G.; Cranmer, S. Employability skills initiatives in higher education: What effects do they have on graduate labour market outcomes? Educ. Econ. 2009, 17, 1-30. [CrossRef]

13. Bybee, R.W. Advancing STEM education: A 2020 vision. Technol. Eng. Teach. 2010, 70, 30.

14. Lowden, K.; Hall, S.; Elliot, D.; Lewin, J. Employers' Perceptions of the Employability Skills of New Graduates; University of Glasgow SCRE Centre and Edge Foundation: London, UK, 2011; pp. 1-43.

15. Carracedo, F.S.; Soler, A.; Martín, C.; López, D.; Ageno, A.; Cabré, J.; García, J.; Gibert, K. Competency maps: An effective model to integrate professional competencies across a STEM curriculum. J. Sci. Educ. Technol. 2018, 27, 448-468. [CrossRef]

16. Jang, H. Identifying 21st century STEM competencies using workplace data. J. Sci. Educ. Technol. 2016, 25, 284-301. [CrossRef]

17. ABET (2020): Criteria for Accrediting Engineering Programs, 2019-2020. Available online: https://www.abet.org/accreditation/ accreditation-criteria/criteria-for-accrediting-engineering-programs-2019-2020/E001-15-16-EAC-Criteria-03-10-15.pdf (accessed on 16 July 2021).

18. Pejcinovic, B. Design of Rubrics for Student Outcomes in 2019-2020 ABET Criteria. In Proceedings of the 43rd International Convention on Information and Communication Technology, Electronics and Microelectronics (MIPRO), Opatija, Croatia, 28 September-2 October 2020.

19. Handelsman, J.; Ebert-May, D.; Beichner, R.; Bruns, P.; Chang, A.; DeHaan, R.; Wood, W.B. Scientific Teaching. Available online: http:/ / www.palieducationsociety.org/images/ebooks\%20(34).pdf (accessed on 6 August 2021).

20. Freeman, S.; Eddy, S.L.; McDonough, M.; Smith, M.K.; Okoroafor, N.; Jordt, H.; Wenderoth, M.P. Active learning increases student performance in science, engineering, and mathematics. Proc. Natl. Acad. Sci. USA 2014, 111, 8410-8415. [CrossRef] [PubMed]

21. Benson, L.C.; Orr, M.K.; Biggers, S.B.; Moss, W.F.; Ohland, M.W.; Schiff, S.D. Student-centered active, cooperative learning in engineering. Int. J. Eng. Educ. 2010, 26, 1097.

22. Rahman, A.; Al-Amin, M. Teaching of fluid mechanics in engineering course: A student-centered blended learning approach. In Using Technology Tools to Innovate Assessment, Reporting, and Teaching Practices in Engineering Education; Alam, F., Ed.; IGI Global: Hershey, PA, USA, 2014; pp. 12-20. [CrossRef]

23. Petersen, C.I.; Baepler, P.; Beitz, A.; Ching, P.; Gorman, K.S.; Neudauer, C.L.; Rozaitis, W.; Walker, J.D.; Wingert, D. The tyranny of content: "Content coverage" as a barrier to evidence-based teaching approaches and ways to overcome it. CBE Life Sci. Educ. 2020, 19, ar17. [CrossRef] [PubMed]

24. Shay, J.E.; Pohan, C. Resilient Instructional Strategies: Helping Students Cope and Thrive in Crisis. J. Microbiol. Biol. Educ. 2021, 22. [CrossRef] [PubMed]

25. Fazey, I.; Fazey, J.A.; Fischer, J.; Sherren, K.; Warren, J.; Noss, R.F.; Dovers, S.R. Adaptive capacity and learning to learn as leverage for social-ecological resilience. Front. Ecol. Environ. 2007, 5, 375-380. [CrossRef]

26. Barnes, K.; Marateo, R.C.; Pixy, F.S. Teaching and learning with the net generation. Innovate J. Online Educ. $2007,3,1-9$.

27. Berk, R. Teaching strategies for the net generation. Transform. Dialogues Teach. Learn. J. 2009, 3, 1-24.

28. Helsper, E.J.; Eynon, R. Digital natives: Where is the evidence? Br. Educ. Res. J. 2010, 36, 503-520. [CrossRef]

29. Carroll, D.W. Patterns of student writing in a critical thinking course: A quantitative analysis. Assess. Writ. 2007, 12, 213-227. [CrossRef]

30. Torres-Madroñero, E.M.; Torres-Madroñero, M.C.; Ruiz Botero, L.D. Challenges and Possibilities of ICT-Mediated Assessment in Virtual Teaching and Learning Processes. Future Int. 2020, 12, 232. [CrossRef]

31. Chen, B.; Bastedo, K.; Howard, W. Exploring best practices for online STEM courses: Active learning, interaction \& assessment design. Online Learn. 2018, 22, 59-76. Available online: https://olj.onlinelearningconsortium.org/index.php/olj/article/view/13 69 (accessed on 6 August 2021).

32. Talbert, R. The Case for Space in Flipped Learning. Available online: https://rtalbert.org/case-for-space-flipped-learning/ (accessed on 16 July 2021).

33. Talbert, R. Flipped Learning: A Guide for Higher Education Faculty; Stylus Publishing LLC: Sterling, VA, USA, 2017.

34. Prieto, A.; Barbarroja, J.; Álvarez, S.; Corell, A. Eficacia del modelo de aula invertida (flipped classroom) en la enseñanza universitaria: Una síntesis de las mejores evidencias Effectiveness of the flipped classroom model in university education: A synthesis of the best evidence. Revista de Educación 2021, 391, 149-177. 
35. Salem, A.A. Engaging ESP University Students in Flipped Classrooms for Developing Functional Writing Skills, HOTs, and Eliminating Writer's Block. Engl. Lang. Teach. 2018, 11, 177-198. [CrossRef]

36. Lasfeto, D. The relationship between self-directed learning and students' social interaction in online learning environment. J. e-Learn. Knowl. Soc. 2020, 16, 34-41.

37. Theobald, E.J.; Hill, M.J.; Tran, E.; Agrawal, S.; Arroyo, E.N.; Behling, S.; Chambwe, N.; Cintrón, D.L.; Cooper, J.D.; Dunster, G.; et al. Active learning narrows achievement gaps for underrepresented students in undergraduate science, technology, engineering, and math. Proc. Natl. Acad. Sci. USA 2020, 117, 6476-6483. [CrossRef] [PubMed]

38. Singh, S.; Arya, A. A hybrid flipped-classroom approach for online teaching of biochemistry in developing countries during Covid-19 crisis. Biochem. Mol. Biol. Educ. A Bimon. Publ. Int. Union Biochem. Mol. Biol. 2020, 48, 502-503. [CrossRef] [PubMed]

39. Hasanah, I.; Arifani, Y. The Effect of Flipped Classroom toward ESP Students Reading Comprehension. In Proceedings of the Borneo International Conference on Education and Social Sciences (BICESS 2018), Gresik, Indonesia, 9-10 September 2020; pp. 226-236. [CrossRef]

40. Hwang, G.J.; Lai, C.L.; Wang, S.Y. Seamless flipped learning: A mobile technology-enhanced flipped classroom with effective learning strategies. J. Comput. Educ. 2015, 2, 449-473. [CrossRef]

41. Sein-Echaluce, M.L.; Fidalgo-Blanco, Á.; Alves, G. Technology behaviors in education innovation. Comput. Hum. Behav. 2017, 72, 596-598. [CrossRef]

42. Caena, F.; Redecker, C. Aligning teacher competence frameworks to 21st century challenges: The case for the European Digital Competence Framework for Educators (Digcompedu). Eur. J. Educ. 2019, 54, 356-369. [CrossRef]

43. Coman, C.; Tîru, L.G.; Meseșan-Schmitz, L.; Stanciu, C.; Bularca, M.C. Online Teaching and Learning in Higher Education during the Coronavirus Pandemic: Students' Perspective. Sustainability 2020, 12, 10367. [CrossRef]

44. Ploj Virtic, M.; Dolenc, K.; Šorgo, A. Changes in Online Distance Learning Behaviour of University Students during the Coronavirus Disease 2019 Outbreak, and Development of the Model of Forced Distance Online Learning Preferences. Eur. J. Educ. Res. 2021, 10, 393-411. [CrossRef]

45. AAAS. Vision and Change in Undergraduate Biology Education: A Call to Action. Available online: https://visionandchange. org/about-vc-a-call-to-action-2011/ (accessed on 16 July 2021).

46. Brewer, C.A.; Smith, D. Vision and Change in Undergraduate Biology Education: A Call to Action; American Association for the Advancement of Science: Washington, DC, USA, 2011; p. 81.

47. Wiggins, G.P.; McTighe, J. The Understanding by Design Guide to Creating High-Quality Units; ASCD: Alexandria, VA, USA, 2011.

48. Krishnamurthi, M. Scaffolding techniques for improving engineering students' writing skills. In Proceedings of the 2009 Annual Conference \& Exposition, Austin, TX, USA, 14 June 2009; pp. 14.1042.1-14.1042.12.

49. Rus, D. Developing technical writing skills to engineering students. Procedia Technol. 2015, 19, 1109-1114. [CrossRef]

50. Tesfie, B.A. Effects of mastery learning instruction on engineering students' writing skills development and motivation. J. Lang. Educ. 2018, 4, 20-30.

51. Côté, J.E.; Allahar, A.L. Lowering Higher Education: The Rise of Corporate Universities and the Fall of Liberal Education; University of Toronto Press: Toronto, ON, Canada, 2011.

52. Boire, G. Lowering Higher Education: The Rise of Corporate Universities and the Fall of Liberal Education. Can. Public Policy 2012, 38, 439-441. [CrossRef]

53. Jones, G.A. Lowering Higher Education: The Rise of Corporate Universities and the Fall of Liberal Education by James E. Côté and Anton L. Allahar; University of Toronto Press: Toronto, ON, Canada, 2013; Volume 82, pp. 474-475.

54. Birnbaum, R. Factors related to university grade inflation. J. High. Educ. 1977, 48, 519-539. [CrossRef]

55. Sabot, R.; Wakeman-Linn, J. Grade inflation and course choice. J. Econ. Perspect. 1991, 5, 159-170. [CrossRef]

56. Manhire, B. Grade Inflation, Ethics, And Engineering Education. In Proceedings of the 2004 Annual Conference, Salt Lake City, UT, USA, 20-23 June 2004; pp. 9-645.

57. Johnson, V.E. Grade Inflation: A Crisis in College Education; Springer Science \& Business Media: Berlin/Heidelberg, Germany, 2006.

58. Cavanaugh, J.K. What did you get? A faculty grade comparison. Qual. Assur. Educ. 2006, 14, 179-186. [CrossRef]

59. Franz, W.J.I. Grade inflation under the threat of students' nuisance: Theory and evidence. Econ. Educ. Rev. 2010, 29, 411-422. [CrossRef]

60. Tucker, J.; Courts, B. Grade inflation in the college classroom. Foresight 2010, 12, 45-53. [CrossRef]

61. Jewell, R.T.; McPherson, M.A.; Tieslau, M.A. Whose fault is it? Assigning blame for grade inflation in higher education. Appl. Econ. 2013, 45, 1185-1200. [CrossRef]

62. Kostal, J.W.; Kuncel, N.R.; Sackett, P.R. Grade inflation marches on: Grade increases from the 1990s to 2000s. Educ. Meas. Issues Pract. 2016, 35, 11-20. [CrossRef]

63. Bachan, R. Grade inflation in UK higher education. Stud. High. Educ. 2017, 42, 1580-1600. [CrossRef]

64. Langbein, L. Management by results: Student evaluation of faculty teaching and the mis-measurement of performance. Econ. Educ. Rev. 2008, 27, 417-428. [CrossRef]

65. Alauddin, M.; Kifle, T. Does the student evaluation of teaching instrument really measure instructors' teaching effectiveness? An econometric analysis of students' perceptions in economics courses. Econ. Anal. Policy 2014, 44, 156-168. [CrossRef]

66. Stroebe, W. Why good teaching evaluations may reward bad teaching: On grade inflation and other unintended consequences of student evaluations. Perspect. Psychol. Sci. 2016, 11, 800-816. [CrossRef] 
67. Bound, J.; Hershbein, B.; Long, B.T. Playing the admissions game: Student reactions to increasing college competition. J. Econ. Perspect. 2009, 23, 119-146. [CrossRef]

68. Marx, J.; Meeler, D. Strike four! Do-over policies institutionalize GPA distortion. Qual. Assur. Educ. 2013, 21, 39-53. [CrossRef]

69. Herron, M.C.; Markovich, Z.D. Student sorting and implications for grade inflation. Ration. Soc. 2017, 29, 355-386. [CrossRef]

70. Mussard, M.; James, A.P. Engineering the global university rankings: Gold standards, limitations and implications. IEEE Access 2018, 6, 6765-6776. [CrossRef]

71. Altınay, F. Examining the role of social interaction in online learning process. Ensayos Revista de la Facultad de Educación de Albacete 2017, 32, 97-106.

72. Cueto-Felgueroso, L.; González-Rodrigo, B.; Santillán, D.; Mosquera-Feijoo, J.C. A tool for boosting the autonomous learning of open channel hydraulics in the framework of flipped classroom. In Proceedings of the 3rd Congreso Internacional de Innovación Educativa en Edificación, CINIE 2019, Madrid, Spain, 6-8 March 2019; pp. 69-70.

73. Febrina, F.; Usman, B.; Muslem, A. Analysis of Reading Comprehension Questions by Using Revised Bloom's Taxonomy on Higher Order Thinking Skill (HOTS). Engl. Educ. J. 2019, 10, 1-15.

74. Azmuddin, R.A.A.; Nor, N.F.M.; Hamat, A. Facilitating Online Reading Comprehension in Enhanced Learning Environment Using Digital Annotation Tools. IAFOR J. Educ. 2020, 8, 7-27. [CrossRef]

75. Friedman, A. What Is Comprehension Reading? 2019. Available online: https://www.theclassroom.com/comprehensionreading-6625410.html (accessed on 6 August 2021).

76. Leung, L.L. An inquiry of teachers' perception on the relationship between higher-order thinking nurturing and liberal studies public assessment in Hong Kong. Teach. Cent. J. 2013, 12, 183-215.

77. Bloom, B.S.; Engelhart, M.D.; Furst, E.J.; Hill, W.H.; Krathwohl, D.R. Taxonomy of educational objectives. In Handbook I: Cognitive Domain; Longman Group Ltd.: London, UK, 1971.

78. Dutkiewicz, A.; Kołodziejczak, B.; Leszczy’n nski, P.; Mokwa-Tarnowska, I.; Topol, P.; Kupczyk, B.; Siatkowski, I. Online Interactivity-A Shift towards E-textbook-based Medical Education. Stud. Log. Gramm. Rhetor 2018, 56, 177-192. [CrossRef]

79. Arifani, Y. The application of small WhatsApp groups and the individual flipped instruction model to boost EFL learners' mastery of collocation. CALL-EJ 2019, 20, 52-73.

80. Arifani, Y.; Asari, S.; Anwar, K.; Budianto, L. Individual or Collaborative "WhatsApp" Learning? A Flipped Classroom Model of EFL Writing Instruction. Teach. Engl. Technol. 2020, 20, 122-139.

81. Robinson, C.M.; Blair, G.M. Writing skills training for engineering students in large classes. High. Educ. 1995, 30, 99-114. [CrossRef]

82. Berthouex, P.M. Honing the writing skills of engineers. J. Prof. Issues Eng. Educ. Pract. 1996, 122, 107-110. [CrossRef]

83. Oakley, B.; Connery, B.; Allen, K. Incorporating writing skills into the engineering curriculum. In Proceedings of the FIE'99 Frontiers in Education. 29th Annual Frontiers in Education Conference. Designing the Future of Science and Engineering Education. Conference Proceedings (IEEE Cat. No. 99CH37011), San Juan, PR, USA, 10-13 November 1999; Volume 3. [CrossRef]

84. Boyd, G.; Hassett, M.F. Developing critical writing skills in engineering and technology students. J. Eng. Educ. 2000, 89, 409-412. [CrossRef]

85. Wilkes, J.; Godwin, J.; Gurney, L.J. Developing information literacy and academic writing skills through the collaborative design of an assessment task for first year engineering students. Aust. Acad. Res. Libr. 2015, 46, 164-175. [CrossRef]

86. Yalvac, B.; Smith, H.D.; Troy, J.B.; Hirsch, P. Promoting advanced writing skills in an upper-level engineering class. J. Eng. Educ. 2007, 96, 117-128. [CrossRef]

87. Kolmos, A.; de Graaff, E. Problem-based and project-based learning in engineering education. Camb. Handb. Eng. Educ. Res. 2014, $1,141-161$.

88. Fredricks, J.A.; Mccolskey, W. The Measurement of Student Engagement: A Comparative Analysis of Various Methods and Student Self-report Instruments. In Handbook of Research on Student Engagement; Christenson, S., Reschly, A., Wylie, C., Eds.; Springer: Boston, MA, USA, 2012. [CrossRef]

89. Guglielmino, P.J.; Guglielmino, L.M. Are your learners ready for e-learning. In AMA Handbook of Online Learning; American Management Association: New York, NY, USA, 2002.

90. Gewin, V. Five tips for moving teaching online as COVID-19 takes hold. Nature 2020, 580, 295-296. [CrossRef] [PubMed]

91. Picciano, A.G. Beyond student perceptions: Issues of interaction, presence, and performance in an online course. J. Asynchronous Learn. Netw. 2002, 6, 21-40. [CrossRef]

92. Liu, Z.; Zhang, N.; Peng, X.; Liu, S.; Yang, Z.; Peng, J.; Chen, J. Exploring the Relationship Between Social Interaction, Cognitive Processing and Learning Achievements in a MOOC Discussion Forum. J. Educ. Comput. Res. 2021. [CrossRef]

93. Sadler, D.R. Formative Assessment: Revisiting the territory. Assess. Educ. Princ. Policy Pract. 1998, 5, 77-84. [CrossRef]

94. Sadler, D. Assessment \& Evaluation in Higher Education Interpretations of criteria-based assessment and grading in higher education. Assess. Eval. High. Educ. 2005, 30, 175-194.

95. Braun, H.; Singer, J. Assessment for monitoring of education systems: International comparisons. Ann. Am. Acad. Pol. Soc. Sci. 2019, 683, 75-92. [CrossRef]

96. Petchamé, J.; Iriondo, I.; Villegas, E.; Fonseca, D.; Romero Yesa, S.; Aláez, M. A Qualitative Approach to Help Adjust the Design of Management Subjects in ICT Engineering Undergraduate Programs through User Experience in a Smart Classroom Context. Sensors 2021, 21, 4762. [CrossRef] 
97. Black, P.; Wiliam, D. Assessment and classroom learning. Assess. Educ. Princ. Policy Pract. 1998, 5, 7-74. [CrossRef]

98. Black, P.; Harrison, C.; Lee, C.; Marshall, B.; Wiliam, D. Working inside the black box: Assessment for learning in the classroom. Phi Delta Kappan 2004, 86, 8-21. [CrossRef]

99. Talanquer, V. La importancia de la evaluación formativa. Educ. Quími. 2015, 26, 177-179. [CrossRef]

100. Beatty, I.D.; Gerace, W.J. Technology-enhanced formative assessment: A research-based pedagogy for teaching science withclassroom response technology. J. Sci. Educ. Technol. 2009, 18, 146-162. [CrossRef]

101. Wilson, J.H.; Wilson, S.B. The First Day of Class Affects Student Motivation: An Experimental Study. Teach. Psychol. 2007, 34, 226-230. [CrossRef]

102. Mosquera Feijóo, J.C.; Suárez, F.; Chiyón, I.; Alberti, M.G. Some Web-Based Experiences from Flipped Classroom Techniques in AEC Modules during the COVID-19 Lockdown. Educ. Sci. 2021, 11, 211. [CrossRef]

103. Rapanta, C.; Botturi, L.; Goodyear, P.; Guàrdia, L.; Koole, M. Online university teaching during and after the Covid-19 crisis: Refocusing teacher presence and learning activity. Postdigital Sci. Educ. 2020, 2, 923-945. [CrossRef]

104. Darby, F. How to Be a Better Online Teacher. The Chronicle of Higher Education. 2019. Available online: http:/ / maui.hawaii. edu/pd/wp-content/uploads/2021/06/How_to_Be_a_Better_Online_Teacher_pdf-The-Chronicle-of-HIgher-Education.pdf (accessed on 7 October 2021).

105. Edström, K.; Kolmos, A. PBL and CDIO: Complementary models for engineering education development. Eur. J. Eng. Educ. 2014, 39, 539-555. [CrossRef]

106. Leung, L. Unwillingness-to-communicate and college students' motives in SMS mobile messaging. Telemat. Inform. 2007, 24, 115-129. [CrossRef]

107. Yeung, S.Y. Conceptualizing higher-order thinking for reforming school curriculum and teaching. Hong Kong Teach. Cent. J. 2012, 11,131-144.

108. Van Loon, J.E.; Lai, H.L. Information Literacy Skills as a Critical Thinking Framework in the Undergraduate Engineering Curriculum. Library Scholarly Publications Paper 80. 2014. Available online: http://digitalcommons.wayne.edu/libsp/80 (accessed on 7 October 2021).

109. Narayanan, S.; Adithan, M. Analysis of question papers in engineering courses with respect to HOTS (Higher Order Thinking Skills). Am. J. Eng. Educ. (AJEE) 2015, 6, 1-10. [CrossRef]

110. Alkhatib, O.J. A Framework for Implementing Higher-Order Thinking Skills (Problem-Solving, Critical Thinking, Creative Thinking, and Decision-Making) in Engineering \& Humanities. In Proceedings of the 2019 Advances in Science and Engineering Technology International Conferences (ASET), Dubai, United Arab Emirates, 26 March-10 April 2019; pp. 1-8. 